Jurnal KIBASP (Kajian Bahasa, Sastra dan Pengajaran)

Volume 1, Nomor 2, Juni 2018

e-ISSN : $2597-5218$

p-ISSN : 2597-520X

DOI: https://doi.org/10.31539/kibasp.v1i2.219

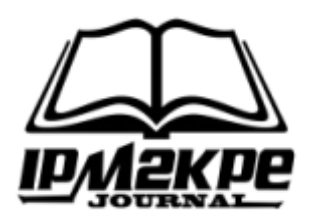

\title{
KOHESI PADA NOVEL CINTA SUCI ZAHRANA KARYA HABIBURAHMAN EL SHIRAZY
}

\author{
Ira Yuniati ${ }^{1}$, Chairunnisa ${ }^{2}$ \\ Universitas Muhammadiyah Bengkulu ${ }^{1}$, STKIP Kusumanegara ${ }^{2}$ \\ irayuniati72@yahoo.co.id ${ }^{1}$
}

Submit, 10-05-2018 Accepted, 11-06-2018 Publish, 22-06-2018

\begin{abstract}
ABSTRAK
Penelitian ini bertujuan untuk mengetahui pemarkah kohesi apa saja yang digunakan dalam novel Cinta Suci Zahrana khususnya pada sub bab terakhir yang berjudul Cinta Suci Zahrana. Penelitian ini menggunakan metode penelitian kualitatif dengan teknik analisis isi (content analysis). Data dalam penelitian ini berupa kohesi dalam Novel Cinta Suci Zahrana karya Habiburrahman El Shirazy. Sumber data berupa Novel Cinta Suci Zahrana karya Habiburrahman El Shirazy. Data mengenai kohesi dalam Novel Cinta Suci Zahrana karya Habiburrahman El Shirazy dianalisis dengan langkah-langkah melacak hubungan setiap dua kalimat secara berpasangan, yaitu hubungan antara sebuah kalimat dengan sebuah kalimat yang mendahuluinya yang ditandai oleh penggunaan pemarkah kohesi. Hasil penelitian berdasarkan mekanisme pemarkah kohesi antara kalimat yang terdapat dalam novel Cinta Suci Zahrana karya Habiburrahman El Shirazy terdapat kohesi gramatikal yang meliputi pengacuan, penggantian, pelesapan, dan perangkaian. Selain itu juga kohesi leksikal yang digunakan yang meliputi repetisi, antonimi, kolokasi, hiponimi, dan ekuivalensi.
\end{abstract}

Kata Kunci: Kohesi, Novel, Analisis Wacana

\begin{abstract}
This study aims to determine the cohesion marker used in the Cinta Suci Zahrana novel especially in the last chapter titled Cinta Suci Zahrana. This research uses qualitative research method with content analysis technique. The data in this research is cohesion in Novel Cinta Suci Zahrana by Habiburrahman El Shirazy. The source of data is the novel of Cinta Suci Zahrana by Habiburrahman El Shirazy. The data on the cohesion in the novel of the Cinta Suci Zahrana by Habiburrahman El Shirazy is analyzed by steps in tracking the relationship of every two sentences in pairs, ie the relationship between a sentence with a preceding sentence characterized by the use of the cohesion marker. The results of research based on cohesion mechanisms between the sentences contained in the novel Cinta Suci Zahrana by Habiburrahman El Shirazy there is a grammatical cohesion which includes referring, replacing, and sequencing. In addition, lexical cohesion is used which includes repetition, antonymy, collocation, hyponimi, and equivalence.
\end{abstract}

Keywords: Cohesion, Novels, Discourse Analysis 


\section{PENDAHULUAN}

Bahasa memegang peranan penting dalam kehidupan manusia, yaitu sebagai alat komunikasi untuk menyampaikan gagasan, pikiran, pendapat dan perasaan. Dengan adanya bahasa sebagai alat komunikasi, maka semua yang berada di sekitar manusia mendapat tanggapan dalam pikiran manusia, disusun dan diungkapkan kembali kepada orang lain sebagai bahan komunikasi. Dalam kehidupan sehari-hari komunikasi melalui bahasa dapat berlangsung secara lisan maupun tertulis dan dapat pula berlangsung dalam jarak dekat maupun jauh.

Dalam proses komunikasi antarmanusia, ada beberapa komponen yang terlibat di dalamnya, yaitu pihak yang berkomunikasi, dalam hal ini adalah pengirim dan penerima informasi, informasi yang akan disampaikan, dan alat yang digunakan dalam menyampaikan informasi. Salah satu alat yang digunakan untuk menyampaikan informasi tersebut adalah simbol atau lambang misalnya bahasa. Bahasa yang digunakan untuk berkomunikasi sangatlah beragam. Hal ini bergantung pada masyarakat pemakai bahasa.

Sebagai negara kepulauan, Indonesia memiliki bahasa yang berbeda-beda antara satu daerah dengan daerah lain. Perbedaan bahasa daerah ini tidaklah menghalangi komunikasi dan perkembangan beberapa sektor kehidupan karena adanya satu bahasa kesatuan atau bahasa nasional yaitu bahasa Indonesia. Bahasa nasional inilah yang menjembatani semua proses komunikasi yang ada di negara Indonesia.

Undang-Undang Republik Indonesia tentang Sistem Pendidikan Nasional telah menetapkan bahwa bahasa Indonesia sebagai bahasa negara menjadi bahasa pengantar dalam Pendidikan Nasional. Dengan demikian, betapa penting dan strategisnya penguasaan bahasa Indonesia bagi setiap peserta didik yang sedang dan akan menuntut ilmu di semua jenjang pendidikan di Indonesia.

Menurur Tarigan (1986), keterampilan berbahasa ada empat aspek, yaitu: keterampilan menyimak (listening skills), (2) keterampilan berbicara (speaking skills), (3) keterampilan membaca (reading skills), dan (4) keterampilan menulis (writing skills).Keempat aspek keterampilan berbahasa tersebut merupakan satu kesatuan yang tidak dapat dipisahkan satu sama lain, tetapi hanya bisa dibedakan. Keterampilan yang satu, bergantung kepada ketiga keterampilan yang lainnya. Keterampilan menyimak dan 
membaca disebut aspek reseptif atau aspek pemahaman, sedangkan keterampilan berbicara dan menulis disebut aspek produktif atau aspek penggunaan. Keempat aspek keterampilan berbahasa dimaksud merupakan wujud nyata dari kegiatan berkomunikasi. Penguasaan atas keempat aspek keterampilan berbahasa dimaksud menjadi sasaran utama dari pembelajaran bahasa Indonesia.

Menurut Tarigan (1986:), menulis merupakan suatu keterampilan berbahasa yang dipergunakan untuk berkomunikasi secara tidak langsung, tidak secaratatap muka dengan orang lain. Dari keempat keterampilan berbahasa tersebut, menulis dianggap sebagai pelajaran yang sulit dipelajari dan dipraktikan. Hal itu diperkuat oleh pernyataan Heaton (1989) yang mengatakan bahwa menulis merupakan kegiatan yang sangat kompleks dan kadang-kadang sulit untuk diajarkan, karena menulis bukan hanya sekedar mengungkapkan ide dan perasaan dengan menggunakan kata-kata yang tepat serta susunan kalimat yang efektif dengan aturan tatatulis yang benar, tetapi menulis memerlukan berbagai keterampilan yang menunjang keberhasilannya seperti keterampilan mekanik, keterampilan stilistika, keterampilan menilai, dan keterampilan berpikir dan mengembangkannya.

Kemampuan menulis itu hanya dapat dicapai melalui latihan yang intensif dan bimbingan yang sistematis. Latihan menulis tidak hanya berkisar pada penuangan ide atau gagasan semata, melainkan bagaimana gagasan itu mengandung makna yang utuh yang tidak menyebabkan adanya kesalahpahaman. Dengan latihan menulis, penulis akan mampu mengembangkan kreatifitasnya dan mampu mengkomunikasikan gagasan ataupun perasaannya dengan jelas kepada pembaca.

Untuk menghindari terjadinya kesalahpahaman, penulis harus memperhatikan beberapa faktor yang penting dalam proses penulisan. Faktor-faktor tersebut adalah caracara mengolah, menyusun, merangkai dan mengorganisasi informasi secara logis dan serasi sehingga menjadi bentuk tulisan atau karangan sesuai dengan formalitas tulisan. Tulisan yang baik adalah tulisan yang mempunyai ciri-ciri, di antaranya bermakna, jelas/lugas, merupakan kesatuan yang bulat, singkat dan padat, memenuhi kaidah kebahasaan dan bersifat komunikatif.

Menurut McCrimmon (1967), dalam kegiatan menulis, seorang penulis harus terampil memanfaatkan grafologi, struktur bahasa, dan kosakata. Keterampilan menulis 
digunakan untuk mencatat, merekam, meyakinkan, melaporkan, menginformasikan, dan mempengaruhi pembaca. Maksud dan tujuan seperti itu hanya dapat dicapai dengan baik oleh para pembelajar yang dapat menyusun dan merangkai jalan pikiran dan mengemukakannya secara tertulis dengan jelas, lancar, dan komunikatif. Kejelasan ini bergantung pada pikiran, organisasi, pemakaian dan pemilihan kata, dan struktur kalimat.

Kegiatan menulis juga harus mempertimbangkan tujuan penulisan. Jika seseorang penulis bertujuan untuk menghibur pembaca, maka ia akan memilih bentuk tulisan yang bukan bertujuan untuk meyakinkan pembaca. Untuk itu, seorang penulis harus mampu memilih bentuk tulisan secara tepat. Menurut D’Angelo (1986), bentuk tulisan dapat diperinci menjadi wacana informatif, wacana persuasif, wacana sastra, dan wacana ekspresi diri. Sementara itu, Keraf (1995) mengatakan bahwa bentuk wacana terdiri dari eksposisi, argumentasi, persuasi, deskripsi, dan narasi. Selanjutnya Vivian (1961) mengatakan bahwa bentuk tulisan itu dapat diklasifikasikan menjadi eksposisi, argumentasi, deskripsi dan narasi. Menurut Schiffrin (1994), wacanamengadungduapengertian berdasarkan kajian yang dianalisis dari wacana.Pengertianpertamaberdasarkanpendekatanstruktural (formalis), wacanamerupakan unit bahasa di atas kalimat atau beberapa kalimat yang memiliki hubungan dan struktur bahasa baik secara kohesi dan koherensi. Pengertian kedua berdasarkan pendekatan fungsionalis, wacana diartikan penggunaan bahasa yang melihat struktur tuturan (tindakan dan peristiwa) sebagai cara bertutur yang memiliki makna.

Kegiatan menulis dilaksanakan di seluruh jenjang pendidikan, dari mulai pendidikan anak-anak (dasar) sampai dengan jenjang pendidikan tinggi. Karangan yang dibuat siswa dapat berbentuk tulisan eksposisi, argumentasi, deskripsi dan narasi. Materi pembelajaran tentang kohesi di SMA kurang sekali mendapat perhatian oleh guru. Bahkan guru kurang sekali menilai hasil karangan siswa berdasarkan kekohesian karangan. Hal ini karena materi pembelajaran tentang kohesi tidak secara ekplisit terdapat dalam kurikulum. Materi tentang kohesi tidak disajikan tersendiri, tetapi terpadu dalam pembelajaran keterampilan berbahasa.

Kohesi merujuk keperpautan bentuk, yang berbeda dengan koherensi yang merujuk pada perpautan makna. Pada umumnya karangan yang baik memiliki keduaduanya. Kalimat atau kata yang dipakai itu berkaitan; pengertian yang satu menyambung 
pengertian yang lain secara berturut-turut. Meskipun kohesi dan koherensi umumnya berpautan, tidaklah berarti bahwa kohesi harus ada agar wacana menjadi koheren. Menurut Halliday dan Hasan (1976), secara garis besar kohesi dibagi menjadi dua, yaitu kohesi gramatikal yang terdiri dari referensi (pengacuan), substitusi (penyulihan), elipsis (pelesapan), relasi konjungsi. Selanjutnya kohesi leksikal yang terdiri dari repetisi (perulangan), sinonimi (sama makna), antonimi (beroposisi makna), dan hiponimi kolokasi (collocation).

Penelitian kohesi pada dasarnya bukanlah penelitian baru. Penelitian tentang kohesi sudah pernah dilakukan juga oleh Parwati (2010) dalam jurnalnya yang berjudul “Kohesi Leksikal Repetisi Pada Wacana Wayang Durangpo dalam Surat Kabar Harian Jawa Pos Edisi Februari-April 2010”. Perbedaan dengan penelitian yang peneliti lakukan, yaitu dalam penelitian ini, peneliti meneliti semua aspek kohesi yang terdapat dalam novel Cinta Suci Zahrana tersebut, baik itu kohesi leksikal maupun kohesi gramatikal.

Bertolak dari apa yang dikemukakan di atas, penelitian ini mencoba menelaah salah satu aspek dari telaah teks atau telaah wacana, yaitu tentang kohesi dalam novel Cinta Suci Zahrana yang diharapkan dapat dijadikan sebagai salah satu contoh dalam pembelajaran menulis di sekolah. Peneliti menganalisis bagian akhir dari sub-bab pada novel ini karena judul akhir ini begitu berkesan bagi peneliti karena mengisahkan bagaimana tokoh Zahrana ini yang begitu tegar dan kuat dalam menjalani hidupnya, yang akhirnnya dapat memiliki karir yang baik, pendidikan yang cemerlang, dan keluarga yang harmonis. Semoga, dengan melakukan analisis kohesi pada wacana novel ini, diharapkan dapat menambah semangat belajar siswa dalam menulis karena selain menganalisis siswa juga dapat menikmati alur cerita yang mengesankan sehingga suatu karya sastra tidak hanya digunakan dalam pembelajaran hanya untuk menganalisis unsur atau strukturnya saja tetapi juga dapat digunakan sebagai bahan pembelajaran dalam membentuka kalimat yang kohesi.

\section{METODE PENELITIAN}

Penelitian ini menggunakan metode penelitian kualitatif dengan teknik analisis isi (content analysis). Penelitian ini mempunyai ciri deskriptif karena data yang dikumpulkan 
berupa kata-kata dan bukan berupa angka-angka. Karena itu, hasil penelitian ini nanti berupa deskripsi yang disertai dengan kutipan-kutipan data yang Novel Cinta Suci Zahrana karya Habiburrahman El Shirazy, yang diberi interpretasi sesuai dengan teknik kajian kohesi.

Data mengenai kohesi dalam Novel Cinta Suci Zahrana karya Habiburrahman El Shirazy dianalisis dengan langkah-langkah melacak hubungan setiap dua kalimat secara berpasangan, yaitu hubungan antara sebuah kalimat dengan sebuah kalimat yang mendahuluinya yang ditandai oleh penggunaan pemarkah kohesi.

\section{HASIL PENELITIAN}

Berdasarkan hasil analisis yang telah dilakukan, dapat diketahui bahwa dalam novel Cinta Suci Zahrana terdapat kohesi gramatikal yang terdiri dari pengacuan, penggantian, pelesapan, dan perangkaian.Sedangkan kohesi leksikal yang digunakan pada Novel Cinta Suci Zahrana khususnya pada sub-bab terakhir dengan judul Cinta Suci Zahrana, meliputi repetisi, antonimi, kolokasi, hiponimi, dan ekuivalensi.

\section{Kohesi Gramatikal}

Pengacuan

(1) Dua minggu setelah Idul Fitri, Zahranamembuka-buka file kartu nama. Iamelihat sebuah nama: Prof. Jiang Daohan, yang tak lain adalah guru besar Fakultas Teknik Fudan University, China.

Pada contoh (1) digunakan unsur pengacuan berupa kata tunjuk 'ia'. Kata 'ia' mengacu pada kata 'Zahrana' pada kalimat sebelumnya.

\section{Penggantian}

(1) Satu bulan setelah itu, Zahrana dan Hasan sudah sampai di China. Mereka datang seminggu lebih awal dari hari yang dijadwalkan oleh Prof. Jiang.

Pada contoh tersebut, terdapat kohesi penggantian, dengan unsur pengganti berupa kata 'mereka'. Kata 'mereka' mengganti kata 'Zahrana dan Hasan' yang disebutkan pada kalimat sebelumnya.

Pelesapan

(1) Ia melihat sebuah nama: Prof. Jiang Daohan, yang tak lain adalah guru besar Fakultas Teknik Fudan University, China. Ia masih ingat saat dulu 
bertemu dengan guru besar yang ramah itu di Grand Auditorium Tsinghua University.

(2) Prof Jiang juga menanyakan apakah Zahrana akan belajar di Fudan sendirian atau membawa keluarga, Zahrana mengatakan akan membawa keluarga. Dan Prof Jiang mengatakan : welcome!

Pada contoh (1) kalimat pertama disebutkan 'Prof. Jiang Daohan'. Pada kalimat kedua kata 'Prof. Jiang Daohan' yang seharusnya disebutkan, tidak dinyatakan secara eksplisit. Jadi, kata 'Prof. Jiang Daohan' mengalami pelesapan. Selain itu, pada kalimat (2) juga mengalami pelesapan pada kata 'Zahrana dan keluarga'.

Perangkaian

(1) Jika mau saya bisa carikan investor dan Anda bisa membuat mahakarya atas ide-ide brilian Anda di bidang arsitektur berbasis budaya. Ini kartu nama saya, kalau Anda tertarik dengan tawaran saya." Dan setelah ia menerima penghargaan sebelum berpisah Prof Jiang Daohan sempat menawari dirinya untuk melanjutkan Ph.D. dengan beasiswa penuh dari Fudan University.

(2) Langkah yang pertama ia lakukan adalah membicarakan keinginannya pada suaminya. Kalau pun suaminya tidak mengijinkan dan memilih agar ia menemani suaminya belajar di Malaysia ia tetap siap. Tetapi jika suaminya mengijinkan maka ia akan lebih bahagia.

(3) Prof Jiang juga menanyakan apakah Zahrana akan belajar di Fudan sendirian atau membawa keluarga, Zahrana mengatakan akan membawa keluarga. Dan Prof Jiang mengatakan : welcome!

Pada contoh (1) digunakan kohesi perangkaian menggunakan konjungsi 'Dan' untuk menghubungkan kalimat kedua dan ketiga. Selain sebagai penghubung, kata 'Dan' juga menandai hubungan penambahan informasi. Pada contoh (2) digunakan kata penghubung berupa kata 'kalau pun' dan kata 'tetapi'. Digunakan kata penghubung tersebut untuk menghubungkan kalimat pertama dan kalimat kedua dan penghubung kalimat kedua dan ketiga yang mengandung hubungan perturutan sebagai kalimat penjelas terhadap kalimat pertama. Kata penghubung yang digunakan pada contoh (3) berupa kata 'dan'. Kata ini menghubungkan kalimat kedua dengan kalimat ketiga yang berfungsi sebagai penghubung antarkalimat. 


\section{Kohesi Leksikal}

Repetisi

(1) "Sebelumnya saya ucapkan selamat ya, buat Anda, buat Indonesia. Saya sudah membaca tulisan-tulisan Anda, ide-ide Anda. Sangat bagus. Jika mau saya bisa carikan investor dan Anda bisa membuat mahakarya atas ide-ide brilian Anda di bidang arsitektur berbasis budaya. Ini kartu nama saya, kalau Anda tertarik dengan tawaran saya.

Pada contoh (1), kata 'saya' dan kata 'Anda' yang terdapat pada kalimat pertama mengalami pengulangan pada beberapa kalimat selanjutnya. Kata yang diulang tersebut terletak pada posisi yang sama, yakni di awal dan akhir kalimat.

Sinonim

(1) Saya sudah membaca tulisan-tulisan Anda, ide-ide Anda sangat bagus. Jika mau saya bisa carikan investor dan Anda bisa membuat mahakarya atas ideide brilian Anda di bidang arsitektur bebasis budaya.

Kata yang mengandung hubungan sinonimi pada potongan wacana (1) di atas adalah kata 'ide-ide Anda sangat bagus' yang terdapat pada kalimat pertama dengan kata ‘ ide-ide brilian Anda'. Kedua kata tersebut memiliki makna yang sama, yakni baik/bagus/hebat/luar biasa pada suatu hasil karya seni ciptaan seseorang.

Antonim

(1) Kalaupun suaminya tidak mengijinkan dan memilih agar ia menemani suaminya belajar di Malaysia ia tetap siap. Tetapi jika suaminya mengijinkan maka ia akan lebih bahagia.

Pada kutipan di atas, hubungan antonimi terjalin antara kata 'tidak mengijinkan' pada kalimat pertama dan kata 'mengijinkan' pada kalimat kedua.

Kolokasi

(1) Selesai S3 semoga Dik Zahrana bisa mengajar di sana, saya terus lanjut sampai selesai S3, setelah kita berdua meraih gelar Doktor, kita pulang. "Tolong kamu faxkan ke saya, nomor paspor kamu, biografi singkat kamu, dan transkrip nilai akademi $\mathbf{S 1}$ dan $\mathbf{S 2}$ kamu.

Hubungan kolokasi pada potongan wacana (1) terjalin antara kalimat pertama dan kedua. Pada kalimat pertama dinyatakan sejumlah jenjang pendidikan seperti 'S1, S2, dan 
S3. Kata-kata seperti S1, S2, dan S3, merupakan contoh kata yang cenderung dipakan secara berdampingan dalam domain atau jaringan pendidikan.

Hiponimi

(1) Mereka datang seminggu lebih awal dari hari yang dijadwalkan oleh Prof Jiang. Sebab mereka ingin merasakan indahnya bulan madu di Negeri Tirai Bambu itu. Zahrana mengajak Hasan ke Tiananmen, Istana Musim Panas, Istana Kota Terlarang, dan tentu saja ke Tembok Raksasa.

Pada contoh (1) hiponim kata 'Negeri Tirai Bambu' terdapat pada kalimat kedua, yaitu Tiananmen, Istana Musim Panas, Istana Kota Terlarang, dan tentu saja ke Tembok Raksasa.

Ekuivalensi

Ekuivalensi merupakan hubungan kesepadanan antara satuan lingual tertentu dengan satuan lingual lain dalam sebuah paradigma. Hubungan ekuivalensi ditunjukkan oleh kata hasil afiksasi dengan morfem asal yang sama. Berikut potongan wacana yang mengandung hubungan ekuivalensi.

(1) Zahrana bahagia sekali, saking bahagianya ia peluk suaminya dan ia hadiahi ciuman penuh cinta.

Pada contoh di atas, satuan lingual yang memiliki hubungan kesepadanan adalah kata 'bahagia' dan 'bahagianya'. Kedua kata tersebut memiliki bentuk dasar yang sama, yakni 'bahagia'. Melalui kohesi leksikal berupa ekuivalensi atau kesepadanan, akan tercipaya sebuah wacana yang kohesif.

\section{PEMBAHASAN}

\section{Kohesi Gramatikal}

Kohesi gramatikal yang terdapat dalam penggalan novel Cinta Suci Zahrana terutama pada bab terakhir meliputi pengacuan, penggantian, pelesapan, dan perangkaian.

Pengacuan

Pengacuan merupakan kohesi gramatikal berupa satuan lingual yang mengacu atau menunjuk satuan lingual lainnya. Terdapat dua unsur yang terlibat, yaitu unsur yang mengacu (pengacu) dan acuannya. Berdasar letak acuannya, di dalam atau di luar wacana, pengacuan dibedakan menjadi endofora dan eksofora. 
Pengacuan endofora

Pengacuan endofora merupakan pengacuan yang acuannya berada di dalam teks wacana. Berdasar arah acuannya, pengacuan endofora dibedakan menjadi pengacuan anaforis dan pengacuan kataforis.

Pengacuan anaforis

Disebut pengacuan anaforis apabila letak unsur yang menjadi acuan mendahului satuan lingal yang mengacunya. Berdasarkan penelitian yang telah dilakukan, pengacuan endofora yang bersifat anaforis yang terdapat dalam cerita novel Cinta Suci Zahrana terdapat pada potongan cerita yang di antaranya sebagai berikut:

(1) Dua minggu setelah Idul Fitri, Zahranamembuka-buka file kartu nama. Iamelihat sebuah nama: Prof. Jiang Daohan, yang tak lain adalah guru besar Fakultas Teknik Fudan University, China.

Pada contoh (1) digunakan unsur pengacuan berupa kata tunjuk 'ia'. Kata 'ia' mengacu pada kata 'Zahrana' pada kalimat sebelumnya.

(2) Ia melihat sebuah nama: Prof. Jiang Daohan, yang tak lain adalah guru besar Fakultas Teknik Fudan University, China. Ia masih ingat saat dulu bertemu dengan guru besar yang ramah itu di Grand Auditorium Tsinghua University.

Pada contoh (2) digunakan unsur pengacuan berupa frasa 'guru besar yang ramah itu' merupakan unsur penunjuk yang mengacu pada 'Prof. Jiang Daohan.

(3) Zahrana tersenyum, ia teringat kata-kata yang diucapkan Prof. Jiang Daohan saat memberinya selamat. "Sebelumnya saya ucapkan selamat ya, buat Anda, buat Indonesia. Saya sudah membaca tulisan-tulisan Anda, ideide Anda. Sangat bagus.

Pada contoh (3), digunakan unsur pengacuan berupa kata tunjuk 'saya' yang mengacu pada kata 'Prof. Jiang Daohan' pada kalimat sebelumnya. Dan juga digunakan kata tunjuk 'buat Anda, buat Indonesia' yang merupakan unsur penunjuk yang mengacu pada kata 'Zahrana' pada kalimat sebelumnya, yang mana tokoh Zahrana merupakan sebagai seorang arsitek handal dari Indonesia.

(4) Zahrana terpikir untuk sekolah lagi, mengambil program doktor di Fudan University, China. Itu jika tawaran Prof. Jiang Daohan masih berlaku dan juga suaminya, Hasan Baktinusa mengijinkan. 
Pada contoh (4), digunakan unsur pengacuan berupa kata tunjuk 'itu' yang mengacu pada frasa 'sekolah lagi, mengambil program doktor di Fudan University, China' pada kalimat sebelumnya. Selain itu, akhiran '-nya' yang melekat pada kata 'suaminya' berperan sebagai unsur pengacu yang melekat pada kata 'Zahrana' pada kalimat sebelumnya.

(5) Prof. Jiang ternyata tidak lupa. Tawaran itu masih berlaku selama dia masih aktif sebagai guru besar di Fudan University.

Pada contoh (5) digunakan unsur pengacuan berupa kata 'dia' yang mengacu pada kata untuk menyebutkan nama tokoh 'Prof. Jiang' yang terdapat pada kalimat sebelumnya.

(6) Satu bulan setelah itu, Zahrana dan Hasan sudah sampai di China. Mereka datang seminggu lebih awal dari hari yang dijadwalkan oleh Prof. Jiang, sebab mereka ingin merasakan indahnya bulan madu di Negeri Tirai Bambu itu.

Pada contoh (6) digunakan unsur pengacuan berupa kata tunjuk 'mereka' yang mengacu pada frasa 'Zahrana dan Hasan' pada kalimat sebelumnya. Selain itu, terdapat juga unsur pengacuan berupa frasa 'Negeri Tirai Bambu itu' sebagai unsur pengacu yang melekat pada kata 'di China' pada kalimat sebelumya.

(7) Zahrana mengajak Hasan menginap di Hotel Jianguo. Tempat di mana dia pernah menginap.

Pada contoh (7) digunakan unsur pengacuan berupa kalimat 'tempat di mana dia pernah menginap' yang mengacu pada kata tempat 'di Hotel Jianguo' pada kalimat sebelumnya. Selain itu, digunakan juga unsur pengacuan berupa kata tunjuk 'dia' mengacu pada kata 'Zahrana; pada kalimat sebelumnya.

(8) Zahrana mengajak Hasan ke Tiananmen, Istana Musim Panas, Istana Kota Terlarang, dan tentu saja ke Tembok Raksasa. Dua sejoli yang dipenuhi rasa bahagia dan saling mencintai itu berjalan-berjalan di Tembok Raksasa sambil menghirup sejuknya musim semi.

Pada contoh (8) digunakan unsur pengacuan berupa ungkapan kata 'dua sejoli' yang mengacu pada frasa kata 'Zahrana mengajak Hasan’ pada kalimat sebelumnya.

(9) “Benar kau tidak menyesal menikah denganku?” Ucap Zahrana pelan. "Demi Allah tidak, justru aku merasa sangat beruntung bisa menikah dengan perempuan yang salehah, seperti engkau. 
Pada contoh (9) digunakan unsur pengacuan berupa frasa kata 'perempuan yang salehah' dan kata 'engkau' yang mengacu pada kata pada nama tokoh 'Zahrana' pada kalimat sebelumnya. Pengacuan yang terdapat pada beberapa contoh tersebut merupakan pengacuan endofora karena acuannya berada dalam teks wacana dan bersifat anaforis karena acuannya mendahului unsur pengacunya.

\section{Pengacuan Kartaforis}

Pengacuan kataforis merupakan salah satu kohesi gramatikal yang berupa satuan lingual tertentu yang mengacu pada satuan linguaa lain yang mengikutinya, atau mengacu anteseden di sebelah kanan. Berikut potongan wacana yang menggunakan kohesi pengacuan berupa pengacuan endofora yang bersifat kataforis.

(1) Langkah yang pertama ia lakukan adalah membicarakan keinginannya pada suaminya. Kalaupun suaminya tidak mengijinkan dan memilih agar ia menemani suaminya belajar di Malaysia ia telah siap. Tetapi jika suaminya mengijinkan maka ia akan lebih bahagia. Ia menyampaikan semuanya dengan terbuka dan apa adanya. Di luar dugaan Hasan ternyata sangat antusias menyambut keinginan Zahrana.

Pada potongan wacana (1), digunakan kata 'ia', 'suami', dan akhiran 'nya' sebagai unsur pengacu, sedangkan acuannya berada pada kalimat berikutnya. Kata 'ia' adalah acuan dari nama tokoh yang disebutkan pada kalimat berikutnya, yaitu 'Zahrana'. Kata 'suami' adalah acuan dari nama tokoh yang disebutkan pada kalimat berikutnya, yaitu 'Hasan'. Dan akhiran '-nya' tersebut melekat pada kata 'suami' membentuk kata 'suaminya'. Acuan dari akhiran '-nya' tersebut adalah nama tokoh yang disebutkan pada kalimat berikutnya, yaitu 'Zahrana'. Pengacuan pada contoh (1) merupakan pengacuan endofora karena acuannya berada di dalam teks wacana. Acuan pada potongan wacana ini berada setelah unsur pengacu, sehingga pengacuannya bersifat karaforis.

(2) "Kalau tidak ada universitas yang mau menerima kita, kita dirikan perguruan tinggi sendiri. Kata Hasan. Zahrana bahagia sekali.

Pada potongan wacana (2) digunakan kata 'kita' sebagai unsur pengacu, sedangkan acuannya berada pada kalimat berikutnya. Kata 'kita' tersebut adalah untuk menyebutkan nama tokoh yang disebutkan pada kalimat berikutnya, yaitu 'Hasan dan Zahrana'. 
(3) Dalam genggaman tangan suaminya ia merasakan aliran cinta yang suci, cinta yang berbalut keindahan sunnah Nabi. Zahrana melepaskan genggamannya lalu berbalik dan memegang lengan suaminya.

Pada potongan wacana (3), digunakan kata 'ia' sebagai unsur pengacu, sedangkan acuannya berada pada kalimat berikutnya. Kata 'ia' tersebut adalah sebutan untuk menyebutkan nama tokoh yang disebutkan pada kalimat berikutnya, yaitu 'Zahrana' Pengacuan Eksofora

Disebut pengacuan eksofora apabila acuannya berada di luar teks wacana. Pengacuan eksofora pada penelitian ini menggunakan kata ganti persona 'aku' sebagai penanda. Penggunaan pengacuan eksofora tampak pada contoh berikut:

(1) Justru aku merasa sangat beruntung bisa menikah dengan perempuan salehah, seperti engkau. Aku merasa sangat beruntung. Aku sangat mencintaimu.

(2) "Langit, matahari melihat kita. Aku malu. Kita perlu menjaga adab dan tatakrama. Itulah cinta yang suci.”

Contoh (1), (2), dan (3) menggunakan pengacuan eksofora karena acuannya berada di luar teks wacana. Unsur pengacu yang digunakan adalah kata ganti persona pertama, yakni 'aku' yang terdapat pada contoh kalimat tersebut. Acuannya adalah penulis karangan, yang berada di luar teks wacana.

\section{Penggantian}

Penggantian merupakan salah satu jenis kohesi gramatikal berupa penggantian unsur tertentu dengan unsur lain untuk memperoleh unsur pembeda. Berikut ini potongan wacana yang mengandung kohesi penggantian.

(2) Satu bulan setelah itu, Zahrana dan Hasan sudah sampai di China. Mereka datang seminggu lebih awal dari hari yang dijadwalkan oleh Prof. Jiang.

Pada contoh tersebut, terdapat kohesi penggantian, dengan unsur pengganti berupa kata 'mereka'. Kata 'mereka' mengganti kata 'Zahrana dan Hasan' yang disebutkan pada kalimat sebelumnya.

Pelesapan

Pelesapan adalah kohesi gramatikal berupa penghilangan atau pelesapan unsur kalimat yang telah disebutkan sebelumnya. Walaupun dihilangkan, unsur kalimat tersebut 
masih dapat diperkirakan keberadaannya. Pelesapan digunakan sebagai salah satu cara untuk menghindari pengulangan kata yang sama yang bisa menimbulkan kebosanan pada pembaca.

(3) Ia melihat sebuah nama: Prof. Jiang Daohan, yang tak lain adalah guru besar Fakultas Teknik Fudan University, China. Ia masih ingat saat dulu bertemu dengan guru besar yang ramah itu di Grand Auditorium Tsinghua University.

(4) Prof Jiang juga menanyakan apakah Zahrana akan belajar di Fudan sendirian atau membawa keluarga, Zahrana mengatakan akan membawa keluarga. Dan Prof Jiang mengatakan : welcome!

Pada contoh (1) kalimat pertama disebutkan 'Prof. Jiang Daohan'. Pada kalimat kedua kata 'Prof. Jiang Daohan' yang seharusnya disebutkan, tidak dinyatakan secara eksplisit. Jadi, kata 'Prof. Jiang Daohan' mengalami pelesapan. Selain itu, pada kalimat (2) juga mengalami pelesapan pada kata 'Zahrana dan keluarga'. Kata tersebut seharusnya dinyatakan secara eksplisit, akan tetapi tidak ditulis. Berikut potongan wacana (1) dan (2) jika tidak mengalami pelesapan.

(1) Ia melihat sebuah nama: Prof. Jiang Daohan, yang tak lain adalah guru besar Fakultas Teknik Fudan University, China. Ia masih ingat saat dulu bertemu dengan Prof. Jiang Daohan, guru besar yang ramah itu di Grand Auditorium Tsinghua University.

(2) Prof Jiang juga menanyakan apakah Zahrana akan belajar di Fudan sendirian atau membawa keluarga, Zahrana mengatakan akan membawa keluarga. Dan Perangkaian Prof Jiang mengatakan : welcome, Zahrana dan keluarga!

Perangkaian adalah salah satu jenis kohesi gramatikal yang menghubungkan unsur yang satu dengan unsur yang lain dalam wacana. Berdasarkan penelitian yang dilakukan, diketahui bahwa konjungsi antarkalimat yang digunakan dalam Novel Cinta Suci Zahrana karya Habiburrahman El Shirazy terdiri atas:

(4) Jika mau saya bisa carikan investor dan Anda bisa membuat mahakarya atas ide-ide brilian Anda di bidang arsitektur berbasis budaya. Ini kartu nama saya, kalau Anda tertarik dengan tawaran saya." Dan setelah ia menerima penghargaan sebelum berpisah Prof Jiang Daohan sempat menawari dirinya untuk melanjutkan Ph.D. dengan beasiswa penuh dari Fudan University. 
(5) Langkah yang pertama ia lakukan adalah membicarakan keinginannya pada suaminya. Kalau pun suaminya tidak mengijinkan dan memilih agar ia menemani suaminya belajar di Malaysia ia tetap siap. Tetapi jika suaminya mengijinkan maka ia akan lebih bahagia.

(6) Prof Jiang juga menanyakan apakah Zahrana akan belajar di Fudan sendirian atau membawa keluarga, Zahrana mengatakan akan membawa keluarga. Dan Prof Jiang mengatakan : welcome!

Pada contoh (1) digunakan kohesi perangkaian menggunakan konjungsi 'Dan' untuk menghubungkan kalimat kedua dan ketiga. Selain sebagai penghubung, kata 'Dan' juga menandai hubungan penambahan informasi. Pada contoh (2) digunakan kata penghubung berupa kata 'kalau pun' dan kata 'tetapi'. Digunakan kata penghubung tersebut untuk menghubungkan kalimat pertama dan kalimat kedua dan penghubung kalimat kedua dan ketiga yang mengandung hubungan perturutan sebagai kalimat penjelas terhadap kalimat pertama. Kata penghubung yang digunakan pada contoh (3) berupa kata 'dan'. Kata ini menghubungkan kalimat kedua dengan kalimat ketiga yang berfungsi sebagai penghubung antarkalimat.

\section{Kohesi Leksikal}

Berdasarkan penelitian yang telah dilakukan, diketahui bahwa kohesi leksikal yang digunakan pada Novel Cinta Suci Zahrana khususnya pada sub-bab terakhir dengan judul Cinta Suci Zahrana, meliputi repetisi, antonimi, kolokasi, hiponimi, dan ekuivalensi.

Repetisi

Repetisi merupakan salah satu sarana kohesi leksikal berupa pengulangan satuansatuan lingual tertentu pada beberapa tempat yang berbeda untuk memberikan tekanan dalam sebuah konteks yang sesuai. Di bawah ini beberapa potongan wacana yang mengandung kohesi leksikal berupa repetisi.

(1) "Sebelumnya saya ucapkan selamat ya, buat Anda, buat Indonesia. Saya sudah membaca tulisan-tulisan Anda, ide-ide Anda. Sangat bagus. Jika mau saya bisa carikan investor dan Anda bisa membuat mahakarya atas ide-ide brilian Anda di bidang arsitektur berbasis budaya. Ini kartu nama saya, kalau Anda tertarik dengan tawaran saya.

(2) Langkah yang pertama ia lakukan adalah membicarakan keinginannya pada suaminya. Kalau pun suaminya tidak mengijinkan dan memilih agar ia menemani suaminya belajar di Malaysia ia tetap siap. Tetapi jika suaminya mengijinkan maka ia akan lebih bahagia. 
Pada contoh (1), kata 'saya' dan kata 'Anda' yang terdapat pada kalimat pertama mengalami pengulangan pada beberapa kalimat selanjutnya. Kata yang diulang tersebut terletak pada posisi yang sama, yakni di awal dan akhir kalimat. Pada contoh (2), kata 'suaminya' yang terdapat pada kalimat pertama mengalami pengulangan pada kalimay berikutnya. Kata yang diulang pada cuplikan wacana (2) ini terletak pada posisi yang berbeda pada kalimat pertama kata 'suaminya' terletak pada akhir kalimat, sedangkan pada kalimat kedua dan ketiga kata 'suaminya' terletak pada awal kalimat. Melalui pengulangan satuan lingual tertentu yang dianggap penting pada beberapa kalimat, baik pada letak yang sama ataupun berbeda, akan menjadikan wacana menjadi kohesif.

Sinonimi

Sinonimi merupakan keadaan di mana dua kata atau lebih memiliki makna yang sama. Berikut kutipan wacana yang mengandung hubungan sinonimi.

(1) Saya sudah membaca tulisan-tulisan Anda, ide-ide Anda sangat bagus. Jika mau saya bisa carikan investor dan Anda bisa membuat mahakarya atas ideide brilian Anda di bidang arsitektur bebasis budaya.

(2) Dalam genggaman tangan suaminya ia merasakan aliran cinta yang suci. Cinta yang berbalut keindahan sunnah Nabi.

Kata yang mengandung hubungan sinonimi pada potongan wacana (1) di atas adalah kata 'ide-ide Anda sangat bagus' yang terdapat pada kalimat pertama dengan kata ‘ ide-ide brilian Anda'. Kedua kata tersebut memiliki makna yang sama, yakni baik/bagus/hebat/luar biasa pada suatu hasil karya seni ciptaan seseorang. Pada kutipan (2) di atas adalah kata 'aliran cinta yang suci' yang terdapat pada kalimat pertama dengan kata 'cinta yang berbalut keindahan sunnah Nabi' pada kalimat kedua. Kedua kata tersebut memiliki makna yang sama, yakni sama-sama cinta yang diridhohi oleh Allah SWT.

Antonimi

Antonimi atau oposisi makna merupakan salah satu sarana kohesi leksikal yang mampu mendukung kepaduan wacana. Dari penelitian ini diketahui terdapat antonimi yang terdapat dalam cerita Novel Cinta Suci Zahrana, diantaranya:

(1) Kalaupun suaminya tidak mengijinkan dan memilih agar ia menemani suaminya belajar di Malaysia ia tetap siap. Tetapi jika suaminya mengijinkan maka ia akan lebih bahagia. 
Pada kutipan di atas, hubungan antonimi terjalin antara kata 'tidak mengijinkan' pada kalimat pertama dan kata 'mengijinkan' pada kalimat kedua.

Kolokasi

Kolokasi merupakan kohesi leksikal berupa relasi makna yang berdekatan antara satu kata dengan kata yang lain dalam sebuah domain atau jaringan tertentu. Di bawah ini potongan wacana yang mengandung kolokasi.

(1) Selesai S3 semoga Dik Zahrana bisa mengajar di sana, saya terus lanjut sampai selesai S3, setelah kita berdua meraih gelar Doktor, kita pulang. "Tolong kamu faxkan ke saya, nomor paspor kamu, biografi singkat kamu, dan transkrip nilai akademi S1 dan S2 kamu.

(2) Zahrana mengajak Hasan ke Tiananmen, Istana Musim Panas, Istana Kota Terlarang, dan tentu saja ke Tembok Raksasa di Negeri Tirai Bambu, China.

(3) "Langit, matahari melihat kita. Aku malu. Kita perlu menjaga adab dan tatakrama. Ituah cinta yang suci.

(4) Airmata Zahrana meleleh, ia merasa bahagia diberi karunia oleh Allah suami yang shaleh, yang romantis tetapi juga sangat menjaga akhlak, adab, etika, dan tatakrama.

Hubungan kolokasi pada potongan wacana (1) terjalin antara kalimat pertama dan kedua. Pada kalimat pertama dinyatakan sejumlah jenjang pendidikan seperti ' $\mathrm{S} 1$, $\mathrm{S} 2$, dan S3. Kata-kata seperti S1, S2, dan S3, merupakan contoh kata yang cenderung dipakan secara berdampingan dalam domain atau jaringan pendidikan.

Begitu juga pada contoh (2), pada kata 'Tiananmen, Istana Musim Panas, Istana Kota Terlarang, dan tentu saja ke Tembok Raksasa' mengandung relasi makna yang menyatakan nama-nama tempat yang ada di Negeri Tirai Bambu, China. Begitu juga pada kalimat yang terdapat pada contoh (3) 'langit, matahari', dan pada contoh (4) dinyatakan sejumlah sifat yang dimiliki seseorang seperti, 'akhlak, adab, etika, dan tatakrama'. Pada kata sebelumnya disebutkan kata 'shaleh'. Kata-kata seperti 'akhlak, adab, etika, dan tatakrama' merupakan contoh kata yang cenderung dipakai secara berdampingan dalam domain atau jaringan untuk menyatakan sikap seseorang.

Hiponimi 
Hiponimi merupakan relasi antarkata yang berwujud atas-bawah, dalam suatu kata maknanya mencakup sejumlah komponen lain. Kata yang berkedudukan sebagai kelas atas atau yang mencakupi komponen yang lebih kecil disebut superordinat sedangkan kata yang dicakupi oleh komponen lain yang lebih besar disebut hiponim. Contoh penggunan hiponimi tampak pada potongan wacana berikut.

(1) Mereka datang seminggu lebih awal dari hari yang dijadwalkan oleh Prof Jiang. Sebab mereka ingin merasakan indahnya bulan madu di Negeri Tirai Bambu itu. Zahrana mengajak Hasan ke Tiananmen, Istana Musim Panas, Istana Kota Terlarang, dan tentu saja ke Tembok Raksasa.

(2) Airmata Zahrana meleleh, ia merasa bahagia diberi karunia oleh Allah suami yang shaleh, yang romantis tetapi juga sangat menjaga akhlak, adab, etika, dan tatakrama.

Pada contoh (1) hiponim kata 'Negeri Tirai Bambu' terdapat pada kalimat kedua, yaitu Tiananmen, Istana Musim Panas, Istana Kota Terlarang, dan tentu saja ke Tembok Raksasa. Pada contoh (2) kata 'sholeh' merupakan superordinat. Hiponimnya, yaitu akhlak, adab, etika, dan tatakrama.

\section{Ekuivalensi}

Ekuivalensi merupakan hubungan kesepadanan antara satuan lingual tertentu dengan satuan lingual lain dalam sebuah paradigma. Hubungan ekuivalensi ditunjukkan oleh kata hasil afiksasi dengan morfem asal yang sama. Berikut potongan wacana yang mengandung hubungan ekuivalensi.

(1) Zahrana bahagia sekali, saking bahagianya ia peluk suaminya dan ia hadiahi ciuman penuh cinta.

Pada contoh di atas, satuan lingual yang memiliki hubungan kesepadanan adalah kata 'bahagia' dan 'bahagianya'. Kedua kata tersebut memiliki bentuk dasar yang sama, yakni 'bahagia'. Melalui kohesi leksikal berupa ekuivalensi atau kesepadanan, akan tercipaya sebuah wacana yang kohesif. 


\section{SIMPULAN}

Hasil penelitian berdasarkan mekanisme pemarkah kohesi antara kalimat yang terdapat dalam novel Cinta Suci Zahrana karya Habiburrahman El Shirazy terdapat kohesi gramatikal yang meliputi pengacuan, penggantian, pelesapan, dan perangkaian. Pengacuan merupakan kohesi gramatikal berupa satuan lingual yang mengacu atau menunjuk satuan lingual lainnya. Penggantian merupakan salah satu jenis kohesi gramatikal berupa penggantian unsur tertentu dengan unsur lain untuk memperoleh unsur pembeda. Pelesapan adalah kohesi gramatikal berupa penghilangan atau pelesapan unsur kalimat yang telah disebutkan sebelumnya. Walaupun dihilangkan, unsur kalimat tersebut masih dapat diperkirakan keberadaannya. Pelesapan digunakan sebagai salah satu cara untuk menghindari pengulangan kata yang sama yang bisa menimbulkan kebosanan pada pembaca. Perangkaian adalah salah satu jenis kohesi gramatikal yang menghubungkan unsur yang satu dengan unsur yang lain dalam wacana.

Selain itu juga kohesi leksikal yang digunakan yang meliputi repetisi, antonimi, kolokasi, hiponimi, dan ekuivalensi. Repetisi merupakan salah satu sarana kohesi leksikal berupa pengulangan satuan-satuan lingual tertentu pada beberapa tempat yang berbeda untuk memberikan tekanan dalam sebuah konteks yang sesuai. Sinonimi merupakan keadaan di mana dua kata atau lebih memiliki makna yang sama. Antonimi atau oposisi makna merupakan salah satu sarana kohesi leksikal yang mampu mendukung kepaduan wacana.Kolokasi merupakan kohesi leksikal berupa relasi makna yang berdekatan antara satu kata dengan kata yang lain dalam sebuah domain atau jaringan tertentu. Ekuivalensi merupakan hubungan kesepadanan antara satuan lingual tertentu dengan satuan lingual lain dalam sebuah paradigma. Hubungan ekuivalensi ditunjukkan oleh kata hasil afiksasi dengan morfem asal yang sama.Melalui kohesi leksikal berupa ekuivalensi atau kesepadanan, akan tercipaya sebuah wacana yang kohesif. 


\section{DAFTAR PUSTAKA}

D’Angelo, Frangky J. (1986). Process and Thought in Composition. Boston: Littte, Brown and Company

Halliday, M. A. K dan Ruqaiya Hasan. (1976). Cohesion in English.London: Longman.

Heaton, J.B. (1989). Writing English Language Test. London: Longman.

Keraf, Gorys. (1995). Eksposisi. Jakarta: Gramedia.

McCrimmon, James M. (1967). Writing With a Purpose. Boston: Houngton Miffin Company.

Parwati, Edin. (2011). Kohesi Leksikal Repetisi Pada Wacana “Wayang Durangpo” dalam Surat Kabar Harian "Jawa Pos" Edisi Februari-April 2010. Jurnal Artikulasi $\begin{array}{llllll}\text { Vol. } & 12 & \text { No. } & 2 & \text { Agustus } & \text { 66-75. }\end{array}$ (http://download.portalgaruda.org/article.php?article=97417\&val=260\&title=KOH ESI\%20LEKSIKAL) (Diakses tanggal 03 Juni 2018.

Schiffrin, Deborah. (1994). Approaches to Discourse. USA: Blackwell Publishing

Tarigan, Henry Guntur. (1985). Pengajaran Wacana. Bandung: Angkasa

Bandung: Angkasa

(1986). Menulis Sebagai Suatu Keterampilan Berbahasa.

Vivian, C. H. (1961). English Composition. New York: Barner \& Nobel Books 